\title{
The Role of PI3K Isoforms in Regulating Bone Marrow Microenvironment Signaling Focusing on Acute Myeloid Leukemia and Multiple Myeloma
}

\author{
Rachel E. Piddock ${ }^{1}$, Kristian M. Bowles ${ }^{1,2}$ and Stuart A. Rushworth ${ }^{1, *}$ \\ 1 Norwich Medical School, University of East Anglia, Norwich Research Park, Norwich NR4 7UQ, UK; \\ r.piddock@uea.ac.uk (R.E.P.); k.bowles@uea.ac.uk (K.M.B.) \\ 2 Department of Haematology, Norfolk and Norwich University Hospitals National Health Service Trust, \\ Norwich NR4 7UY, UK \\ * Correspondence: s.rushworth@uea.ac.uk; Tel.: +44-1603-591690
}

Academic Editor: Marco Falasca

Received: 31 January 2017; Accepted: 24 March 2017; Published: 28 March 2017

\begin{abstract}
Despite the development of novel treatments in the past 15 years, many blood cancers still remain ultimately fatal and difficult to treat, particularly acute myeloid leukaemia (AML) and multiple myeloma (MM). While significant progress has been made characterising small-scale genetic mutations and larger-scale chromosomal translocations that contribute to the development of various blood cancers, less is understood about the complex microenvironment of the bone marrow (BM), which is known to be a key player in the pathogenesis of chronic lymphocytic leukaemia (CLL), AML and MM. This niche acts as a sanctuary for the cancerous cells, protecting them from chemotherapeutics and encouraging clonal cell survival. It does this by upregulating a plethora of signalling cascades within the malignant cell, with the phosphatidylinositol-3-kinase (PI3K) pathway taking a critical role. This review will focus on how the PI3K pathway influences disease progression and the individualised role of the PI3K subunits. We will also summarise the current clinical trials for PI3K inhibitors and how these trials impact the treatment of blood cancers.
\end{abstract}

Keywords: AML; myeloma; microenvironment; PI3K

\section{Introduction}

The phosphatidylinositol-3-kinase (PI3K) pathway has been shown to be constitutively active in the majority of multiple myeloma (MM) and acute myeloid leukaemia (AML) cells [1-3] and is critical for the tumour cell growth and survival [4-6]. This activation can be attributed to both the cytokines within the bone marrow microenvironment (BMM) and the adhesion of malignant cells to the extracellular matrix [7-9]. Moreover, disruption of the PI3K pathway has been shown to cause cell cycle arrest and apoptosis in an assortment of cancers [10-12]. Many reviews have highlighted the importance of PI3K in chronic lymphocytic leukaemia (CLL), therefore, this review aims to describe the known individualised roles of the p110 PI3K regulatory subunits (alpha, beta, gamma and delta) in the context of MM and AML. In addition, we will discuss the potential for using PI3K-targeted inhibitors in clinical trials to treat these diseases.

Both MM and AML are haematological malignancies with poor prognoses. Combined, these diseases account for approximately 50,000 deaths per year in the USA [13]. With both AML and MM primarily being diseases of the elderly (average age of diagnosis approx. 67 and 69 years respectively [14]), these malignancies are set to become an ever-increasing problem as life expectancy continues to rise. MM is a cancer of the plasma cell, the terminal differentiation stage of a B-cell, and is characterised by the accumulation of these monoclonal cells within the bone marrow. This can cause 
the patient to develop osteolytic lesions, immunodeficiency and renal failure [15]. In contrast, AML comprises a group of biologically varied disorders of the haematopoietic myeloid progenitor cells which rapidly results in bone marrow failure.

Despite their physiological differences, both of these malignancies at diagnosis are characterised by the expansion of tumorous cells predominantly within the bone marrow. The presence of tumour cells in the peripheral blood is a poor prognostic factor of both diseases and has been linked to a more aggressive or established malignancy $[16,17]$. Within the bone marrow, malignant cells have been shown to be protected from chemotherapy and encouraged to proliferate, grow and migrate [18-21]. Indeed, removal of the cells from this environment into culture results in rapid apoptosis, emphasising the symbiotic relationship between the cancer and the niche in which it proliferates [22,23]. For many patients, current chemotherapies fail to clear the bone marrow of visible disease. Furthermore, even in patients who appear to initially respond well to treatment, a sub-population of cancerous cells defined as minimal residual disease (MRD) may persist and are a primary cause of relapse in this group [24-27]. In the past 20 years, the development of novel treatments has improved MM/AML patient outcome significantly but despite this progress, resistant or relapsed disease remains inevitable for most. The focus of research is now shifting from the malignancy itself to the beneficial stimuli of the environment in which it resides, with the aim of improving therapies with reduced toxicities and ultimately reducing MRD and increasing time between relapse.

\section{Phosphatidylinositol 3-Kinase (PI3K) Activation in Cancer}

PI3Ks are known to aid the regulation of many differing cell functions, including survival and proliferation. The incongruous activation of the PI3K pathway is common to many cancers, and is well described in MM and AML. When activated, PI3K is able to phosphorylate $\mathrm{PIP}_{2}$, a phospholipid component of the cell membrane, to become $\mathrm{PIP}_{3}$ (Figure 1). PIP 3 acts as a docking site for proteins with pleckstrin-homology $(\mathrm{PH})$ domains, which includes the master kinase Phosphoinositide-dependent kinase 1 (PDK1) and its downstream target AKT (also known as protein kinase B). AKT can then activate a plethora of pro-survival signalling cascades, resulting in a reduction in apoptosis and increase in cell motility, survival and growth. Under typical conditions, the lipid phosphatase PTEN (phosphatase and tensin homolog) acts as a negative regulator of the PI3K pathway, de-phosphorylating $\mathrm{PIP}_{3}$ and preventing AKT activation-effectively "turning off" the PI3K pathway. Loss of PTEN functionality has been reported in several cancer types, further enhancing the pro-tumoural effect of the PI3K pathway and correlating with a more aggressive disease phenotype.

There are three classes of PI3Ks, with class I being most frequently linked with cancer development. This class of PI3Ks consists of a regulatory subunit and one of four catalytic subunits: $p 110 \alpha, p 110 \beta$, and p1108 (Class 1A) and p110 $\gamma$ (Class 1B). Whilst a relatively low percentage of PI3K or PTEN mutations are observed in both MM and AML cells [28,29], all four of these isoforms have been shown to be overexpressed in cell lines and primary tissue. p110 $\alpha$ and p110 $\beta$ subunits are expressed ubiquitously in cells. Furthermore, p110 $\mathrm{d}$ and p110 $\gamma$ are known to be specifically enriched by the haematopoietic system - primarily in leukocytes [30]. This is of interest when considering haematological malignancies as it potentially provides a more tissue-specific, localised target for the treatment of white blood cell malignancies with fewer side effects for patients. Below, we have separated the individual PI3K subunits into sections in order to discuss suitability as a target in blood cancers.

\section{1. $p 110 \alpha$}

p110 $\alpha$ has long been associated with many different cancers, including cervical [31] and breast cancer [32]. Increased copy number of the PIK3CA gene and subsequent 3q26.3 amplification was found in a significant percentage of primary tissues in these studies, however this is the only PI3K subunit for which a somatic activation has so far been identified [33,34]. This mutation can often be found in concordance with a loss of PTEN functionality-most commonly in breast, endometrial and colon cancers [35] — further increasing the role of the PI3K pathway in tumorigenesis. 
Despite this mutation being so frequent in solid tumours, it is uncommon in plasma cell disorders and haematological malignancies in general and is only seen at the most advanced stages of plasma cell leukaemia [36]. Recently, it has been shown that inhibition of $\mathrm{p} 110 \alpha$ on its own may not be effective in Luminal Breast Cancer, due to a compensatory rapid accumulation of $\mathrm{PIP}_{3}$ produced by the p110 $\beta$ isoform [37]. This activation, however, did not consistently restore AKT phosphorylation, raising questions about the reliability of phospho-AKT monitored PI3K activation.

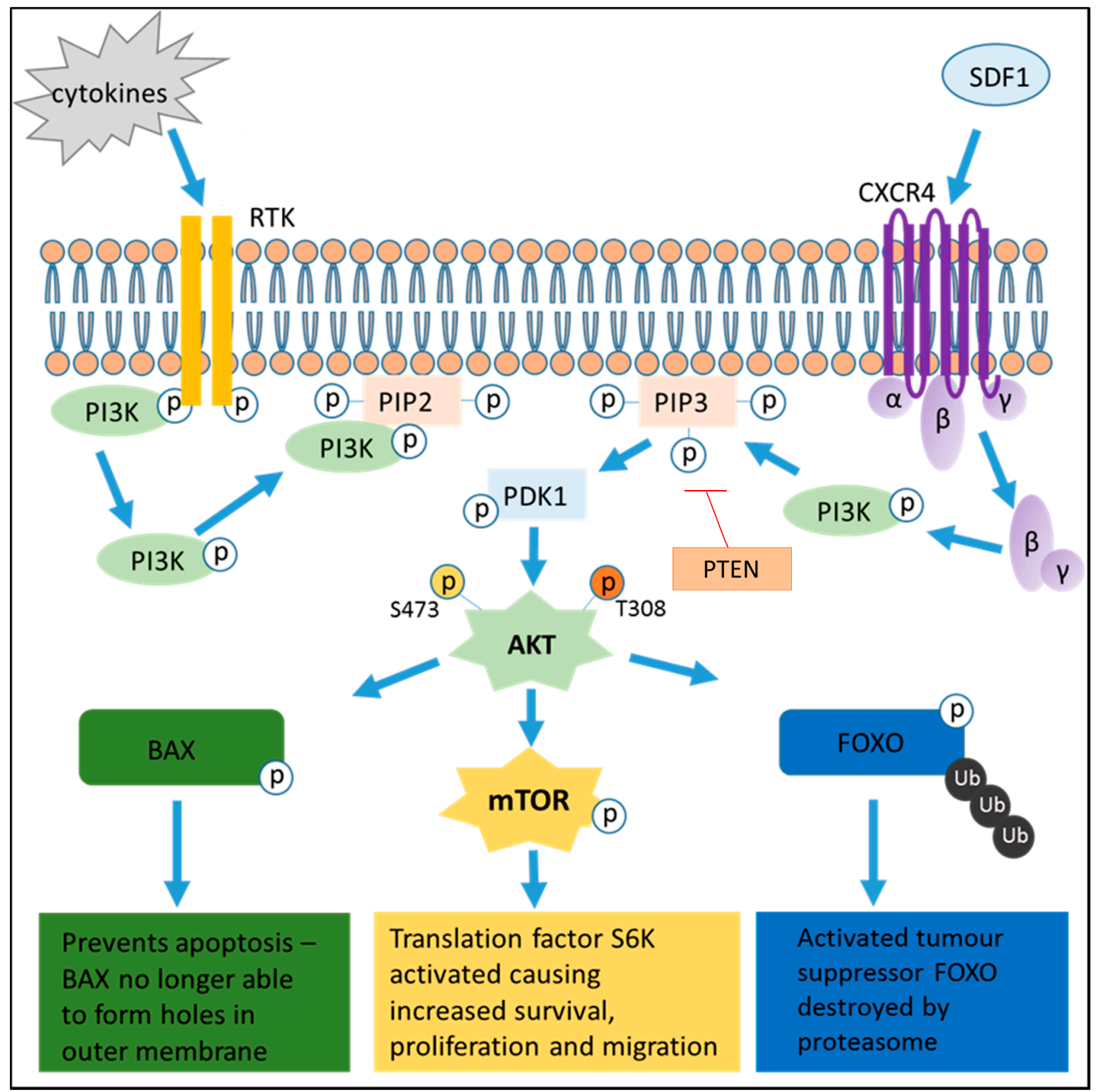

Figure 1. Schematic representation of the phosphatidylinositol-3-kinase (PI3K) pathway. PI3K is phosphorylated via receptor tyrosine kinases (RTKs) and G-protein coupled receptors (GCPRs) located in the cell surface membrane. This causes activation of AKT and its downstream targets, resulting in increased cell survival and migration.

\section{2. $p 110 \beta$}

p110 $\beta$ has been linked to platelet aggregation [38] and is unique in that it has been shown to be activated by both receptor tyrosine kinases (RTK) and G-protein coupled receptors (GCPR) [39]. Mutations in the PIK3CB gene are rare, however increased expression of this gene has been observed in prostate cancer [40], with knockdown (KD) of this gene resulting in increased apoptosis and cell cycle 
arrest in stage G1. p110 $\beta$ has been shown to be required to maintain PI3K signalling in PTEN-deficient cancer cells, indicating the opportunity for isoform-specific inhibition in the treatment of this cancer type [41]. In MM, the necessity for p110 $\beta$ is not yet established-with knockdown (KD) of this gene so far reported as proving to be insignificant in terms of cell survival [42]. AML cells however have been shown to become sensitised to chemotherapeutics upon $110 \beta \mathrm{KD}$, with significant reduction in cell viability [43].

\section{3. $p 110 \delta$}

Alongside $\mathrm{p} 110 \gamma, \mathrm{p} 110 \delta$ plays a critical role in haematological malignancy pathogenesis and in addition has been linked to various immune disorders, such as PI3K $\delta$ syndrome and inflammatory bowel disease [44,45]. p110 has a critical role in B-Cell development and has been shown to have an oncogenic role in a number of blood cancers, including CLL, acute lymphoblastic leukaemia (ALL), MM and AML [6,46,47]. This has led to the development of p1108-specific inhibitors, discussed below, that have been shown to slow and reduce tumour growth, even in the presence of protective bone marrow microenvironment (BMM) signalling.

\section{4. $p 110 \gamma$}

p110 $\gamma$ has been shown to have a critical role in GCPR-mediated $\mathrm{PIP}_{3}$ production, which in turn strictly controls cell motility in macrophages [48]. Mutation of the PI3KCG gene has previously been implicated in lung cancer [49] and inhibition of the p110 $\gamma$ subunit resulted in reduced proliferation of these cells in idiopathic pulmonary fibrosis [50]. Considering this isoform's prominent role in macrophage motility, this may provide a therapeutic target in AML.

\section{PI3K Pathway Activation}

The PI3K pathway has been shown to be activated via a wide assortment of receptor tyrosine kinases (RTKs) —including platelet-derived growth factor receptor (PDGFR) [51,52], c-MET [53], insulin-like growth factor-I receptor (IGF-IR) [54] and Fms-Related Tyrosine Kinase 3 (FLT3) [55]. Constitutive activation of these RTKs (either by mutation/duplication of the RTK such as that reported in AML [56] or overexpression of its complimentary ligand) results in the upregulation of this pathway and has been associated with poor patient prognosis in many cancer types [57,58]. As previously mentioned, G-coupled protein receptors have also been linked to PI3K activation, however this is specific to the $\mathrm{p} 110 \delta / \gamma$ subunits and is not yet well defined. Micro-environmental factors that have been shown to directly contribute to both MM and AML pathogenesis (Table 1) have also been associated with PI3K pathway upregulation, inferring the presence of a positive feedback loop. Of these, Interleukin-6 (IL-6) and Stromal-Derived Factor-1 (SDF-1) are arguably the most significant in $\mathrm{MM}$ and AML pathogenesis and have been shown to be stimulated by tumour cell/BMM cell interactions. This special relationship is discussed in more detail below.

\section{The Protective Effect of the Bone Marrow Microenvironment}

The bone marrow microenvironment comprises a plethora of cell types, including macrophages, fibroblastic stromal cells and endothelial cells [59]. In addition to these cells, there is also a vast set of growth factors, cytokines and hormones that contribute to the complex haematopoietic process. The physiologic balance of these soluble factors is influenced by the presence of malignant cells in both AML and MM which results in biological changes within the stromal cells (as well as the malignant cells themselves) to benefit disease progression [60]. This pro-tumoural environment promotes activation of signalling cascades within both benign and malignant cells which inhibit apoptosis, and promote processes such as proliferation and angiogenesis. Many of these soluble factors upregulate the PI3K pathway, a summary of which is shown in Table 1.

IL-6, for example, is critical in MM disease progression, with IL-6 deficient mice unable to develop MM [61] and elevated IL-6 serum levels being associated with poor patient prognosis [62]. In AML, 
in addition to PI3K pathway activation, IL-6 has been shown to activate the Jak/Stat pathway via Stat3 [63] - a pathway that is known to be commonly dis-regulated in a sub-set of AML patients [64]. Therapies that abrogate IL-6 triggered cascades (such as monoclonal antibody therapy [65]) have been shown to help overcome chemotherapy resistant sub-populations of malignant cells. These agents have also achieved remarkable efficacy in clinical trials in both relapsed/refractory MM [66] and AML [67]. Malignant cells are also known to be protected in the BMM when adhered to the extracellular matrix [68-71] (collagen, fibronectin and laminin) or to bone marrow mesenchymal stromal cells (BM-MSCs) [72]. Interestingly, our group has shown that activation of BM-MSC by AML co-culture is not inhibited by the pan-PI3K inhibitor LY294002 [73], thus suggesting that PI3K inhibition in the context of the malignant BMM will not have adverse effects on the surrounding environment. However, these results are from in vitro co-cultures and the translation to in vivo models needs to be further investigated.

Stromal-derived factor 1 (SDF-1), also known as CXCL12, is present in the BMM in high concentrations. It is produced by stromal cells and is a chemo-attractant to both AML and MM cells, causing them to 'home' to the bone marrow [74,75]. As well as mediating cell migration, SDF-1 has been shown to promote haematopoiesis, increasing the proliferation rates of CD34+ cells [76]. Upon binding, MM cells have been shown to undergo growth arrest [77] as well as the upregulation of pro-survival pathways and secretion of cytokines that are beneficial to both the cancerous cells and the environment on which they depend. AML cells too are known to depend on this adhesion, becoming sensitised to chemotherapeutics upon antagonising CXCR4 [78].

In vitro $3 \mathrm{D}$ tissue culture techniques provide a potential improvement to traditional $2 \mathrm{D}$ cultures as they can provide a scaffold on which to grow extracellular components and can be utilised to study the effect of malignant cells in an environment similar to the BM [79]. These technologies offer an alternative to 2D cultures but do not mimic the biological system of the murine models that are currently used to understand the microenvironment in the pathogenesis of MM and AML. The complex nature of the BMM and its interactions with haematological malignancies is an area under intense investigation as we and others believe that targeting the environment could well be a means of eradicating the tumour. There are currently two types of animal models routinely used in the study of blood cancers: (1) injection of malignant cells into immune deficient mice (such as NOD.Cg-Prkdcscid Il2rgtm1Wjl/SzJ (NSG) mice); and (2) the injection of allogenic malignant cells into $\mathrm{C} 57 \mathrm{BL} / 6$ mice. A third model has recently been proposed in which a scaffold is implanted into immune deficient mice that comprises the patient's microenvironment and the malignant cell [80]. There are, however, several limitations of these models when considering the BMM. In the immune deficient mice, the absence of a functional immune system and its interactions with the human malignancy is not representative of a natural tumour environment. Subsequently, compounds that may have shown promise in a pre-clinical setting do not translate well into clinical trials [81].

When looking at allogenic tumour models, it is pertinent to understand that species-species differences do occur. For example, telomerase (which is for the most part inactive in adult human cells) is still active in a murine model, suggesting that murine cells are more likely to undergo malignant transformation [82]. In addition, the gene that codes for the cytokine IL-8 (which is critical for MM disease progression and osteoclastic differentiation [83]) is not present in the murine genome [84]). New models are always in development, and recent work has been done to 'humanise' the mouse bone marrow, with the aim of replicating the natural microenvironment [85]. Briefly, BM-MSCs can be used to reform the bone marrow of a radiation depleted NSG mouse on which a patient's malignant cells are transplanted resulting in 'XactMice' or 'xenochimeric' mice. This step of essentially providing the mice with a bone marrow transplant should make the model a more accurate reflection of a human immune system. 
Table 1. Common cytokines and soluble factors involved in the pathogenesis of haemic malignancies that are also implicated in PI3K/Akt pathway activation.

\begin{tabular}{|c|c|c|c|}
\hline $\begin{array}{l}\text { Soluble } \\
\text { Factor }\end{array}$ & Involvement in MM Pathogenesis & $\begin{array}{l}\text { Involvement in AML } \\
\text { Pathogenesis }\end{array}$ & $\begin{array}{l}\text { Involvement in } \\
\text { PI3K/Akt Pathway }\end{array}$ \\
\hline APRIL & Survival factor for BM plasmablasts [86] & & [87] \\
\hline BAFF & Normal plasma cell development [88] & & {$[87,89]$} \\
\hline IGF-1 & $\begin{array}{l}\text { Induces growth in all MM cell lines, } \\
\text { promotes cell cycle progression }[90,91]\end{array}$ & & [92] \\
\hline IL-6 & $\begin{array}{l}\text { Promotes drug resistance, high levels } \\
\text { associated with poor prognosis }[93,94]\end{array}$ & $\begin{array}{l}\text { Upregulates STAT3 increasing } \\
\text { AML proliferation and } \\
\text { survival [63] }\end{array}$ & {$[95,96]$} \\
\hline IL-8 & $\begin{array}{c}\text { Increases osteoclastogenesis and promotes } \\
\text { angiogenesis [97] }\end{array}$ & $\begin{array}{l}\text { Increases survival, invasion and } \\
\text { proliferation of AML cells [98] }\end{array}$ & [99] \\
\hline MIP-1a & $\begin{array}{l}\text { Increased survival and osteoclast } \\
\text { production [100] }\end{array}$ & & [101] \\
\hline SDF-1 & $\begin{array}{l}\text { Mediates MM homing to the BM; tumour } \\
\text { growth; drug resistance [74] }\end{array}$ & $\begin{array}{l}\text { Mediates AML migration, BTK } \\
\text { shown to be involved }[102,103]\end{array}$ & [104] \\
\hline $\mathrm{TNF} \alpha$ & $\begin{array}{l}\text { Induces expression of pro-survival } \\
\text { factors [105] }\end{array}$ & $\begin{array}{c}\text { Stimulates AML blast growth } \\
\text { via colony stimulating } \\
\text { factor [106] }\end{array}$ & [107] \\
\hline VEGF & $\begin{array}{l}\text { Angiogenesis, promotes MM survival and } \\
\text { attenuates apoptosis [108] }\end{array}$ & $\begin{array}{l}\text { Upregulated, increases rate of } \\
\text { angiogenesis }[109,110]\end{array}$ & [111] \\
\hline
\end{tabular}

\section{Clinical Implications}

Scientific observations on PI3K signalling in cancer have resulted in the development of a number of PI3K pathway inhibitors over the past 15 years, including isoform-specific inhibitors, which are now in clinical trials across a spectrum of haematological malignancies (a selection of recent trials is highlighted in Table 2). The first wave of PI3K pathway inhibitors to reach the clinic were rapalogues (rapamycin and its analogues) which work via inhibiting mTOR, a downstream target of PI3K activation. Although these drugs were effective in several forms of neoplasms (including neuroendocrine tumours [112] and mantle-cell lymphoma [113]), their use as a single agent treatment was limited due to compensatory pathway activation and subsequent resistance. Rapalogue development was closely followed by the use of small molecules that bound to the catalytic site of mTOR [114] and dual pan-class I PI3K/mTOR inhibitors. These second-generation compounds provided an advantage as they could target the PI3K pathway at two points, suppressing both mTORC1/C2 and PI3K itself [115].

The PI3K/Akt pathway has previously been implicated in the stabilisation of Hypoxia inducible factor $1 \alpha(\mathrm{HIF}-1 \alpha)$ which is a key regulator in metabolic adaption to low oxygen [116]. This is achieved via the activation of heat shock proteins (Hsp) including Hsp90 and Hsp70, which are known to act in conjunction as molecular chaperones, and have been shown to be over-expressed in many human cancers [117-119]. The acute role of Hsps has been described in both AML and MM, where they have been shown to be critical for malignant cell growth and survival $[120,121]$. Interestingly, AML blasts with a FMS-like tyrosine kinase 3 (FLT-3) mutation are highly sensitive to the Hsp90 inhibitor Ganetespib [122,123]. Inhibiting the PI3K pathway therefore has the potential to reduce the activity of Hsps, especially in the sub-population of patients with FLT3 mutations.

Pan-PI3K inhibition, although effective, can have dose-limiting and adverse effects including hyperglycaemia and varying gastrointestinal conditions. When used in the treatment of breast cancer, clinical studies showed that approximately $60 \%$ of patients experienced stomatitis with immunosuppression and non-infectious pneumonitis also presenting at high frequency (40\% and 15\% respectively) [124]. The inhibition of the specific PI3K subunits therefore provides a far more attractive and directed option, especially when considering elderly patients. Isoform-specific inhibition would 
be more easily tolerated in combination with traditional chemotherapeutics and could be tailored to the individual nature of the disease. As previously mentioned, p110 $\alpha$ and p110 $\beta$ are expressed

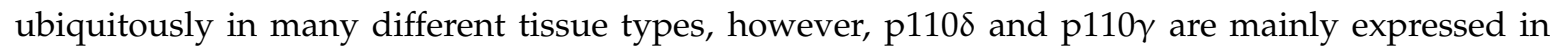
haematopoietic cells. Targeting just the p110 $\delta$ and p110 $\gamma$ isoforms could therefore be beneficial for the treatment of haematological malignancies. Consequently, several isoform-specific PI3K inhibitors have now completed phase III trials for haematological malignancies and have started appearing in clinics worldwide. Idelalisib (p1108 inhibitor), for example, is currently being used in combination with rituximab for the treatment of follicular lymphoma [125], and was previously used for treating CLL [126]. In respect to MM and AML, it would be of great benefit to use these isoform-specific PI3K inhibitors to aid in severing the protective effects these malignant cells experience in the bone marrow.

The full potential of PI3K inhibitors as a complementary therapy has not yet been realised. One interesting combination is the use of PI3K inhibitors in conjunction with programmed cell death protein 1 (PD-1) inhibitors. PD-1 is expressed on activated T-lymphocytes and B cells [127], and inhibition of this receptor effectively results in the immune system 'attacking' malignant cells [128]. However, PD-1 inhibition has been shown to decrease the activity of the PI3K suppressor PTEN, subsequently causing an increase in PI3K pathway activity [129]. PI3K inhibitors could therefore provide relief for this off-target effect and increase the efficacy of PD-1 inhibitors. Despite the plethora of clinical trials involving PD-1 inhibition, there is currently only one phase I clinical trial looking at the combination of PD-1 inhibitor and PI3K inhibitor and this is in solid tumours (NCT02646748). It would be of great interest to see how this inhibition translates into haematological malignancies.

There are, however, drawbacks when considering the PI3K pathway as a therapeutic target. For example, the PI3K pathway has significant overlap with parallel cascades and pharmacological inhibition may result in the activation of these compensatory pathways. These include processes such as NOTCH-MYC amplification [130] or ERK pathway activation [131], reducing the efficacy of treatment. The biomarkers that predict both susceptibility and resistance to PI3K pathway inhibition will also need to be identified, which when considering cancers with multiple sub-populations is highly complex. Also, the current range of PI3K inhibitors lack sensitivity to mutant isoforms and the therapeutic opportunities may therefore be limited. In respect to MM and AML, it would be of great benefit to use these isoform-specific PI3K inhibitors to aid in disrupting the protective effects that these malignant cells experience in the bone marrow. This should increase the efficacy of current chemotherapies and increase the duration of patient remission.

Table 2. Recent PI3K pathway inhibitors in clinical trials for the treatment of common blood cancers. Data taken from ClinicalTrials.gov.

\begin{tabular}{cccccc}
\hline Phase & Status & Drug Name & Target & $\begin{array}{c}\text { Mono/Co } \\
\text { Therapy }\end{array}$ & $\begin{array}{c}\text { ClinicalTrials.Gov. } \\
\text { Number }\end{array}$ \\
\hline I & Completed & Idelalisib & p110 & Mono & NCT01555281 \\
I & Recruiting & CUDC-907 & p110 $\alpha+$ HDAC1/2/3/10 & Mono & NCT01742988 \\
I/II & Completed & Afuresertib & Akt & Co & NCT01476137 \\
I/II & Recruiting & Nelfinavir & pan PI3K & Co & NCT01555281 \\
I/II & Recruiting & ACP-319 & $\mathrm{p} 110 \delta$ & Co & NCT02328014 \\
Ib/II & Completed & BYL719 & $\mathrm{p} 110 \alpha$ & Co & NCT02144038 \\
II & Recruiting & Gedatolisib & $\mathrm{p} 110 \alpha / \gamma+\mathrm{mTOR}$ & Mono & NCT02438761 \\
$\mathrm{III}$ & Ongoing, not recruiting & Duvelisib & $\mathrm{p} 110 \delta / \gamma$ & $\mathrm{Co}$ & NCT02004522 \\
\hline
\end{tabular}

\section{Conclusions}

The PI3K pathway is a major player in terms of cancer development, however the potential individualised roles of its catalytic subunits are yet to be fully defined, with only a small fraction of clinical trials focussing on the PI3K isoforms. The central role of PI3K signalling in many cell types, not just in tumorous tissue, highlights the need for specific subunit inhibition, with the expectation that such a strategy would limit off-target effects and increase the tolerated dosages in vivo. The majority of 
key cytokines involved in AML and MM pathogenesis have been shown to activate the PI3K pathway within the bone marrow microenvironment, accounting for the aberrant activation observed in patient samples where no somatic mutations are present. As PI3K isoform-specific inhibitors enter clinical trials, it remains to be seen the optimal co-therapies with which these drugs are best administered.

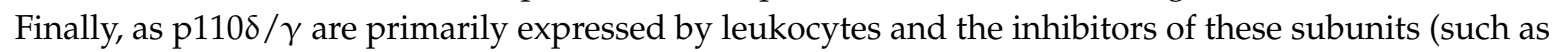
those recently investigated in CLL and lymphoma [132]) have the potential to reverse some of the protective effects of the BMM, it appears that isoform-specific inhibition of p110 $\mathrm{and} /$ or $\gamma$ hold the most promise in haemic malignancies.

Acknowledgments: Rachel E. Piddock is funded by a Ph.D. studentship from the Norwich Research Park DTP (BBSRC). In addition, we would like to thank Yvette Wormstone for proof reading the manuscript.

Conflicts of Interest: Stuart A. Rushworth has research funding from Verastem. All other authors declare no conflict of interest.

\section{References}

1. Maiso, P.; Liu, Y.; Morgan, B.; Azab, A.K.; Ren, P.; Martin, M.B.; Zhang, Y.; Liu, Y.; Sacco, A.; Ngo, H.; et al. Defining the role of TORC1/2 in multiple myeloma. Blood 2011, 118, 6860-6870. [CrossRef] [PubMed]

2. Lindblad, O.; Cordero, E.; Puissant, A.; Macaulay, L.; Ramos, A.; Kabir, N.N.; Sun, J.; Vallon-Christersson, J.; Haraldsson, K.; Hemann, M.T.; et al. Aberrant activation of the PI3K/mTOR pathway promotes resistance to sorafenib in AML. Oncogene 2016, 35, 5119-5131. [CrossRef] [PubMed]

3. Pillinger, G.; Loughran, N.V.; Piddock, R.E.; Shafat, M.S.; Zaitseva, L.; Abdul-Aziz, A.; Lawes, M.J.; Bowles, K.M.; Rushworth, S.A. Targeting PI3K $\delta$ and PI3K $\gamma$ signalling disrupts human AML survival and bone marrow stromal cell mediated protection. Oncotarget 2016, 7, 39784-39795. [PubMed]

4. Ikeda, H.; Hideshima, T.; Fulciniti, M.; Perrone, G.; Miura, N.; Yasui, H.; Okawa, Y.; Kiziltepe, T.; Santo, L.; Vallet, S.; et al. PI3K/p1108 is a novel therapeutic target in multiple myeloma. Blood 2010, 116, 1460-1468. [CrossRef] [PubMed]

5. Billottet, C.; Grandage, V.L.; Gale, R.E.; Quattropani, A.; Rommel, C.; Vanhaesebroeck, B.; Khwaja, A. A selective inhibitor of the p110[delta] isoform of PI 3-kinase inhibits AML cell proliferation and survival and increases the cytotoxic effects of VP16. Oncogene 2006, 25, 6648-6659. [CrossRef] [PubMed]

6. Lannutti, B.J.; Meadows, S.A.; Herman, S.E.M.; Kashishian, A.; Steiner, B.; Johnson, A.J.; Byrd, J.C.; Tyner, J.W.; Loriaux, M.M.; Deininger, M.; et al. CAL-101, a p1108 selective phosphatidylinositol-3-kinase inhibitor for the treatment of B-cell malignancies, inhibits PI3K signaling and cellular viability. Blood 2011, 117, 591-594. [CrossRef] [PubMed]

7. Edelmann, J.; Klein-Hitpass, L.; Carpinteiro, A.; Führer, A.; Sellmann, L.; Stilgenbauer, S.; Dührsen, U.; Dürig, J. Bone marrow fibroblasts induce expression of PI3K/NF-KB pathway genes and a pro-angiogenic phenotype in CLL cells. Leuk. Res. 2008, 32, 1565-1572. [CrossRef] [PubMed]

8. Dong, G.; Chen, Z.; Li, Z.-Y.; Yeh, N.T.; Bancroft, C.C.; Van Waes, C. Hepatocyte Growth Factor/Scatter Factor-induced Activation of MEK and PI3K Signal Pathways Contributes to Expression of Proangiogenic Cytokines Interleukin-8 and Vascular Endothelial Growth Factor in Head and Neck Squamous Cell Carcinoma. Cancer Res. 2001, 61, 5911-5918. [PubMed]

9. Yang, L.; Wang, L.; Lin, H.-K.; Kan, P.-Y.; Xie, S.; Tsai, M.-Y.; Wang, P.-H.; Chen, Y.-T.; Chang, C. Interleukin-6 differentially regulates androgen receptor transactivation via PI3K-Akt, STAT3, and MAPK, three distinct signal pathways in prostate cancer cells. Biochem. Biophys. Res. Commun. 2003, 305, 462-469. [CrossRef]

10. Roy, S.K.; Srivastava, R.K.; Shankar, S. Inhibition of PI3K/AKT and MAPK/ERK pathways causes activation of FOXO transcription factor, leading to cell cycle arrest and apoptosis in pancreatic cancer. J. Mol. Signal. 2010. [CrossRef] [PubMed]

11. Prasad, G.; Sottero, T.; Yang, X.; Mueller, S.; James, C.D.; Weiss, W.A.; Polley, M.-Y.; Ozawa, T.; Berger, M.S.; Aftab, D.T.; et al. Inhibition of PI3K/mTOR pathways in glioblastoma and implications for combination therapy with temozolomide. Neuro-Oncology 2011, 13, 384-392. [CrossRef] [PubMed]

12. Wallin, J.J.; Edgar, K.A.; Guan, J.; Berry, M.; Prior, W.W.; Lee, L.; Lesnick, J.D.; Lewis, C.; Nonomiya, J.; Pang, J.; et al. GDC-0980 Is a Novel Class I PI3K/mTOR Kinase Inhibitor with Robust Activity in Cancer Models Driven by the PI3K Pathway. Mol. Cancer Ther. 2011, 10, 2426-2436. [CrossRef] [PubMed] 
13. Siegel, R.L.; Miller, K.D.; Jemal, A. Cancer statistics, 2015. CA Cancer J. Clin. 2015, 65, 5-29. [CrossRef] [PubMed]

14. Ryerson, A.B.; Eheman, C.R.; Altekruse, S.F.; Ward, J.W.; Jemal, A.; Sherman, R.L.; Henley, S.J.; Holtzman, D.; Lake, A.; Noone, A.M. Annual Report to the Nation on the Status of Cancer, 1975-2012, featuring the increasing incidence of liver cancer. Cancer 2016, 122, 1312-1337. [CrossRef] [PubMed]

15. Palumbo, A.; Anderson, K. Multiple Myeloma. N. Engl. J. Med. 2011, 364, 1046-1060. [CrossRef] [PubMed]

16. Bianchi, G.; Kyle, R.A.; Larson, D.R.; Witzig, T.E.; Kumar, S.; Dispenzieri, A.; Morice, W.G.; Rajkumar, S.V. High levels of peripheral blood circulating plasma cells as a specific risk factor for progression of smoldering multiple myeloma. Leukemia 2013, 27, 680-685. [CrossRef] [PubMed]

17. Feller, N.; Schuurhuis, G.J.; van der Pol, M.A.; Westra, G.; Weijers, G.W.D.; van Stijn, A.; Huijgens, P.C.; Ossenkoppele, G.J. High percentage of CD34-positive cells in autologous AML peripheral blood stem cell products reflects inadequate in vivo purging and low chemotherapeutic toxicity in a subgroup of patients with poor clinical outcome. Leukemia 2003, 17, 68-75. [CrossRef] [PubMed]

18. Meads, M.B.; Hazlehurst, L.A.; Dalton, W.S. The Bone Marrow Microenvironment as a Tumor Sanctuary and Contributor to Drug Resistance. Clin. Cancer Res. 2008, 14, 2519-2526. [CrossRef] [PubMed]

19. Murray, M.Y.; Rushworth, S.A.; Zaitseva, L.; Bowles, K.M.; Macewan, D.J. Attenuation of dexamethasone-induced cell death in multiple myeloma is mediated by miR-125b expression. Cell Cycle 2013, 12, 2144-2153. [CrossRef] [PubMed]

20. Shah, N.M.; Rushworth, S.A.; Murray, M.Y.; Bowles, K.M.; MacEwan, D.J. Understanding the role of NRF2-regulated miRNAs in human malignancies. Oncotarget 2013, 4, 1130-1142. [CrossRef] [PubMed]

21. Shafat, M.S.; Oellerich, T.; Mohr, S.; Robinson, S.D.; Edwards, D.R.; Marlein, C.R.; Piddock, R.E.; Fenech, M.; Zaitseva, L.; Abdul-Aziz, A.; et al. Leukemic blasts program bone marrow adipocytes to generate a protumoral microenvironment. Blood 2017, 129, 1320-1332. [CrossRef] [PubMed]

22. Zlei, M.; Egert, S.; Wider, D.; Ihorst, G.; Wäsch, R.; Engelhardt, M. Characterization of in vitro growth of multiple myeloma cells. Exp. Hematol. 2007, 35, 1550-1561. [CrossRef] [PubMed]

23. Ito, S.; Barrett, A.J.; Dutra, A.; Pak, E.; Miner, S.; Keyvanfar, K.; Hensel, N.F.; Rezvani, K.; Muranski, P.; Liu, P.; et al. Long term maintenance of myeloid leukemic stem cells cultured with unrelated human mesenchymal stromal cells. Stem Cell Res. 2015, 14, 95-104. [CrossRef] [PubMed]

24. Eckert, C.; Biondi, A.; Seeger, K.; Cazzaniga, G.; Hartmann, R.; Beyermann, B.; Pogodda, M.; Proba, J.; Henze, G. Prognostic value of minimal residual disease in relapsed childhood acute lymphoblastic leukaemia. Lancet 2001, 358, 1239-1241. [CrossRef]

25. San Miguel, J.F.; Martínez, A.; Macedo, A.; Vidriales, M.B.; López-Berges, C.; González, M.; Caballero, D.; García-Marcos, M.A.; Ramos, F.; Fernández-Calvo, J.; et al. Immunophenotyping Investigation of Minimal Residual Disease Is a Useful Approach for Predicting Relapse in Acute Myeloid Leukemia Patients. Blood 1997, 90, 2465-2470. [PubMed]

26. Cavo, M.; Terragna, C.; Martinelli, G.; Ronconi, S.; Zamagni, E.; Tosi, P.; Lemoli, R.M.; Benni, M.; Pagliani, G.; Bandini, G.; et al. Molecular monitoring of minimal residual disease in patients in long-term complete remission after allogeneic stem cell transplantation for multiple myeloma. Blood 2000, 96, 355-357. [PubMed]

27. Murray, M.Y.; Zaitseva, L.; Auger, M.J.; Craig, J.I.; MacEwan, D.J.; Rushworth, S.A.; Bowles, K.M. Ibrutinib inhibits BTK-driven NF-kappaB p65 activity to overcome bortezomib-resistance in multiple myeloma. Cell Cycle 2015, 14, 2367-2375. [CrossRef] [PubMed]

28. Chapman, M.A.; Lawrence, M.S.; Keats, J.J.; Cibulskis, K.; Sougnez, C.; Schinzel, A.C.; Harview, C.L.; Brunet, J.-P.; Ahmann, G.J.; Adli, M.; et al. Initial genome sequencing and analysis of multiple myeloma. Nature 2011, 471, 467-472. [CrossRef] [PubMed]

29. Ding, L.; Ley, T.J.; Larson, D.E.; Miller, C.A.; Koboldt, D.C.; Welch, J.S.; Ritchey, J.K.; Young, M.A.; Lamprecht, T.; McLellan, M.D.; et al. Clonal evolution in relapsed acute myeloid leukaemia revealed by whole-genome sequencing. Nature 2012, 481, 506-510. [CrossRef] [PubMed]

30. Koyasu, S. The role of PI3K in immune cells. Nat. Immunol. 2003, 4, 313-319. [CrossRef] [PubMed]

31. Ma, Y.-Y.; Wei, S.-J.; Lin, Y.-C.; Lung, J.-C.; Chang, T.-C.; Whang-Peng, J.; Liu, J.M.; Yang, D.-M.; Yang, W.K.; Shen, C.-Y. PIK3CA as an oncogene in cervical cancer. Oncogene 2000, 19, 2739-2744. [CrossRef] [PubMed]

32. Bachman, K.E.; PArgani; Samuels, Y.; Silliman, N.; Ptak, J.; Szabo, S.; Konishi, H.; Karakas, B.; Blair, B.G.; Lin, C.; et al. The PIK3CA gene is mutated with high frequency in human breast cancers. Cancer Biol. Ther. 2004, 3, 772-775. [CrossRef] [PubMed] 
33. Wu, G.; Xing, M.; Mambo, E.; Huang, X.; Liu, J.; Guo, Z.; Chatterjee, A.; Goldenberg, D.; Gollin, S.M.; Sukumar, S. Somatic mutation and gain of copy number of PIK3CA in human breast cancer. Breast Cancer Res. 2005, 7, R609-R616. [CrossRef] [PubMed]

34. Levine, D.A.; Bogomolniy, F.; Yee, C.J.; Lash, A.; Barakat, R.R.; Borgen, P.I.; Boyd, J. Frequent mutation of the PIK3CA gene in ovarian and breast cancers. Clin. Cancer Res. 2005, 11, 2875-2878. [CrossRef] [PubMed]

35. Yuan, T.L.; Cantley, L.C. PI3K pathway alterations in cancer: Variations on a theme. Oncogene 2008, 27, 5497-5510. [CrossRef] [PubMed]

36. Tiedemann, R.; Gonzalez-Paz, N.; Kyle, R.; Santana-Davila, R.; Price-Troska, T.; van Wier, S.; Chng, W.; Ketterling, R.P.; Gertz, M.; Henderson, K. Genetic aberrations and survival in plasma cell leukemia. Leukemia 2008, 22, 1044-1052. [CrossRef] [PubMed]

37. Costa, C.; Ebi, H.; Martini, M.; Beausoleil, S.A.; Faber, A.C.; Jakubik, C.T.; Huang, A.; Wang, Y.; Nishtala, M.; Hall, B.; et al. Measurement of PIP3 Levels Reveals an Unexpected Role for p110 $\beta$ in Early Adaptive Responses to p110 $\alpha$-Specific Inhibitors in Luminal Breast Cancer. Cancer Cell 2015, 27, 97-108. [CrossRef] [PubMed]

38. Jackson, S.P.; Schoenwaelder, S.M.; Goncalves, I.; Nesbitt, W.S.; Yap, C.L.; Wright, C.E.; Kenche, V.; Anderson, K.E.; Dopheide, S.M.; Yuan, Y.; et al. PI 3-kinase p110beta: A new target for antithrombotic therapy3-kinase p110beta: A new target for antithrombotic therapy. Nat. Med. 2005, 11, 507-514. [CrossRef] [PubMed]

39. Guillermet-Guibert, J.; Bjorklof, K.; Salpekar, A.; Gonella, C.; Ramadani, F.; Bilancio, A.; Meek, S.; Smith, A.J.H.; Okkenhaug, K.; Vanhaesebroeck, B. The p110 $\beta$ isoform of phosphoinositide 3-kinase signals

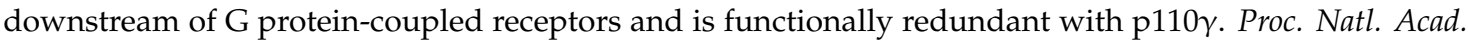
Sci. USA 2008, 105, 8292-8297. [CrossRef] [PubMed]

40. Zhu, Q.; Youn, H.; Tang, J.; Tawfik, O.; Dennis, K.; Terranova, P.F.; Du, J.; Raynal, P.; Thrasher, J.B.; Li, B. Phosphoinositide $3-\mathrm{OH}$ kinase $\mathrm{p} 85 \alpha$ and $\mathrm{p} 110 \beta$ are essential for androgen receptor transactivation and tumor progression in prostate cancers. Oncogene 2008, 27, 4569-4579. [CrossRef] [PubMed]

41. Wee, S.; Wiederschain, D.; Maira, S.-M.; Loo, A.; Miller, C.; deBeaumont, R.; Stegmeier, F.; Yao, Y.-M.; Lengauer, C. PTEN-deficient cancers depend on PIK3CB. Proc. Natl. Acad. Sci. USA 2008, 105, 13057-13062. [CrossRef] [PubMed]

42. Hofmann, C.; Stühmer, T.; Schmiedl, N.; Wetzker, R.; Mottok, A.; Rosenwald, A.; Langer, C.; Zovko, J.; Chatterjee, M.; Einsele, H. PI3K-dependent multiple myeloma cell survival is mediated by the PIK3CA isoform. Br. J. Haematol. 2014, 166, 529-539. [CrossRef] [PubMed]

43. Doepfner, K.T.; Spertini, O.; Arcaro, A. Autocrine insulin-like growth factor-I signaling promotes growth and survival of human acute myeloid leukemia cells via the phosphoinositide 3-kinase/ / Akt pathway. Leukemia 2007, 21, 1921-1930. [CrossRef] [PubMed]

44. Okkenhaug, K.; Bilancio, A.; Farjot, G.; Priddle, H.; Sancho, S.; Peskett, E.; Pearce, W.; Meek, S.E.; Salpekar, A.; Waterfield, M.D.; et al. Impaired B and T Cell Antigen Receptor Signaling in p1108 PI 3-Kinase Mutant Mice. Science 2002, 297, 1031-1034. [PubMed]

45. Lucas, C.L.; Kuehn, H.S.; Zhao, F.; Niemela, J.E.; Deenick, E.K.; Palendira, U.; Avery, D.T.; Moens, L.; Cannons, J.L.; Biancalana, M.; et al. Dominant-activating germline mutations in the gene encoding the PI(3)K catalytic subunit p110[delta] result in T cell senescence and human immunodeficiency. Nat. Immunol. 2014, 15, 88-97. [CrossRef] [PubMed]

46. Sujobert, P.; Bardet, V.; Cornillet-Lefebvre, P.; Hayflick, J.S.; Prie, N.; Verdier, F.; Vanhaesebroeck, B.; Muller, O.; Pesce, F.; Ifrah, N.; et al. Essential role for the p1108 isoform in phosphoinositide 3-kinase activation and cell proliferation in acute myeloid leukemia. Blood 2005, 106, 1063-1066. [CrossRef] [PubMed]

47. Piddock, R.E.; Loughran, N.; Marlein, C.R.; Robinson, S.D.; Edwards, D.R.; Yu, S.; Pillinger, G.E.; Zhou, Z.; Zaitseva, L.; Auger, M.J.; et al. PI3Kdelta and PI3Kgamma isoforms have distinct functions in regulating pro-tumoural signalling in the multiple myeloma microenvironment. Blood Cancer J. 2017, 7, e539. [CrossRef] [PubMed]

48. Hirsch, E.; Katanaev, V.L.; Garlanda, C.; Azzolino, O.; Pirola, L.; Silengo, L.; Sozzani, S.; Mantovani, A.; Altruda, F.; Wymann, M.P. Central Role for G Protein-Coupled Phosphoinositide 3-Kinase $\gamma$ in Inflammation. Science 2000, 287, 1049-1053. [CrossRef] [PubMed] 
49. Belloni, E.; Veronesi, G.; Rotta, L.; Volorio, S.; Sardella, D.; Bernard, L.; Pece, S.; di Fiore, P.P.; Fumagalli, C.; Barberis, M.; et al. Whole exome sequencing identifies driver mutations in asymptomatic computed tomography-detected lung cancers with normal karyotype. Cancer Genet. 2015, 208, 152-155. [CrossRef] [PubMed]

50. Conte, E.; Gili, E.; Fruciano, M.; Korfei, M.; Fagone, E.; Iemmolo, M.; Furno, D.L.; Giuffrida, R.; Crimi, N.; Guenther, A.; et al. PI3K p110[gamma] overexpression in idiopathic pulmonary fibrosis lung tissue and fibroblast cells: In vitro effects of its inhibition. Lab. Investig. 2013, 93, 566-576. [CrossRef] [PubMed]

51. Zhang, H.; Bajraszewski, N.; Wu, E.; Wang, H.; Moseman, A.P.; Dabora, S.L.; Griffin, J.D.; Kwiatkowski, D.J. PDGFRs are critical for PI3K/Akt activation and negatively regulated by mTOR. J. Clin. Investig. 2007, 117, 730-738. [CrossRef] [PubMed]

52. Pickett, E.A.; Olsen, G.S.; Tallquist, M.D. Disruption of PDGFR $\alpha$-initiated PI3K activation and migration of somite derivatives leads to spina bifida. Development 2008, 135, 589-598. [CrossRef] [PubMed]

53. Maulik, G.; Madhiwala, P.; Brooks, S.; Ma, P.; Kijima, T.; Tibaldi, E.; Schaefer, E.; Parmar, K.; Salgia, R. Activated c-Met signals through PI3K with dramatic effects on cytoskeletal functions in small cell lung cancer. J. Cell. Mol. Med. 2002, 6, 539-553. [CrossRef] [PubMed]

54. Torres-Arzayus, M.I.; de Mora, J.F.; Yuan, J.; Vazquez, F.; Bronson, R.; Rue, M.; Sellers, W.R.; Brown, M. High tumor incidence and activation of the PI3K/AKT pathway in transgenic mice define AIB1 as an oncogene. Cancer Cell 2004, 6, 263-274. [CrossRef] [PubMed]

55. Rottapel, R.; Turck, C.W.; Casteran, N.; Liu, X.; Birnbaum, D.; Pawson, T.; Dubreuil, P. Substrate specificities and identification of a putative binding site for PI3K in the carboxy tail of the murine Flt3 receptor tyrosine kinase. Oncogene 1994, 9, 1755-1765. [PubMed]

56. Abu-Duhier, F.; Goodeve, A.; Wilson, G.; Gari, M.; Peake, I.; Rees, D.; Vandenberghe, E.; Winship, P.; Reilly, J. FLT3 internal tandem duplication mutations in adult acute myeloid leukaemia define a high-risk group. Br. J. Haematol. 2000, 111, 190-195. [CrossRef] [PubMed]

57. Ocana, A.; Vera-Badillo, F.; Al-Mubarak, M.; Templeton, A.J.; Corrales-Sanchez, V.; Diez-Gonzalez, L.; Cuenca-Lopez, M.D.; Seruga, B.; Pandiella, A.; Amir, E. Activation of the PI3K/mTOR/AKT Pathway and Survival in Solid Tumors: Systematic Review and Meta-Analysis. PLoS ONE 2014, 9, e95219. [CrossRef] [PubMed]

58. Ying, J.; Xu, Q.; Liu, B.; Zhang, G.; Chen, L.; Pan, H. The expression of the PI3K/AKT/mTOR pathway in gastric cancer and its role in gastric cancer prognosis. Onco Targets Ther. 2015, 8, 2427-2433. [CrossRef] [PubMed]

59. Allen, T.D.; Dexter, T.M. The essential cells of the hemopoietic microenvironment. Exp. Hematol. 1984, 12, 517-521. [PubMed]

60. Colmone, A.; Amorim, M.; Pontier, A.L.; Wang, S.; Jablonski, E.; Sipkins, D.A. Leukemic Cells Create Bone Marrow Niches That Disrupt the Behavior of Normal Hematopoietic Progenitor Cells. Science 2008, 322, 1861-1865. [CrossRef] [PubMed]

61. Zhang, X.; Gaillard, J.P.; Robillard, N.; Lu, Z.Y.; Gu, Z.J.; Jourdan, M.; Boiron, J.; Bataille, R.; Klein, B. Reproducible obtaining of human myeloma cell lines as a model for tumor stem cell study in human multiple myeloma. Blood 1994, 83, 3654-3663. [PubMed]

62. Nachbaur, D.M.; Herold, M.; Maneschg, A.; Huber, H. Serum levels of interleukin-6 in multiple myeloma and other hematological disorders: Correlation with disease activity and other prognostic parameters. Ann. Hematol. 1991, 62, 54-58. [CrossRef] [PubMed]

63. Schuringa, J.J.; Wierenga, A.T.; Kruijer, W.; Vellenga, E. Constitutive Stat3, Tyr705, and Ser727 phosphorylation in acute myeloid leukemia cells caused by the autocrine secretion of interleukin- 6 . Blood 2000, 95, 3765-3770. [PubMed]

64. Lee, H.J.; Daver, N.; Kantarjian, H.M.; Verstovsek, S.; Ravandi, F. The Role of JAK Pathway Dysregulation in the Pathogenesis and Treatment of Acute Myeloid Leukemia. Clin. Cancer Res. 2013, 19, 327-335. [CrossRef] [PubMed]

65. Trikha, M.; Corringham, R.; Klein, B.; Rossi, J.-F. Targeted Anti-Interleukin-6 Monoclonal Antibody Therapy for Cancer. A Review of the Rationale and Clinical Evidence. Clin. Cancer Res. 2003, 9, 4653-4665. [PubMed]

66. Richardson, P.G.; Barlogie, B.; Berenson, J.; Singhal, S.; Jagannath, S.; Irwin, D.; Rajkumar, S.V.; Srkalovic, G.; Alsina, M.; Alexanian, R.; et al. A phase 2 study of bortezomib in relapsed, refractory myeloma. N. Engl. J. Med. 2003, 348, 2609-2617. [CrossRef] [PubMed] 
67. Horton, T.M.; Perentesis, J.P.; Gamis, A.S.; Alonzo, T.A.; Gerbing, R.B.; Ballard, J.; Adlard, K.; Howard, D.S.; Smith, F.O.; Jenkins, G.; et al. A Phase 2 study of bortezomib combined with either idarubicin/cytarabine or cytarabine/etoposide in children with relapsed, refractory or secondary acute myeloid leukemia: A report from the Children's Oncology Group. Pediatr. Blood Cancer 2014, 61, 1754-1760. [CrossRef] [PubMed]

68. Kortlepel, K.; Bendall, L.J.; Gottlieb, D.J. Human acute myeloid leukaemia cells express adhesion proteins and bind to bone marrow fibroblast monolayers and extracellular matrix proteins. Leukemia 1993, 7, 1174-1179. [PubMed]

69. Landowski, T.H.; Olashaw, N.E.; Agrawal, D.; Dalton, W.S. Cell adhesion-mediated drug resistance (CAM-DR) is associated with activation of NF-kB (RelB/p50) in myeloma cells. Oncogene 2003, 22, 2417-2421. [CrossRef] [PubMed]

70. Hazlehurst, L.A.; Dalton, W.S. Mechanisms Associated with cell Adhesion Mediated Drug Resistance (CAM-DR) in Hematopoietic Malignancies. Cancer Metastasis Rev. 2001, 20, 43-50. [CrossRef] [PubMed]

71. Matsunaga, T.; Takemoto, N.; Sato, T.; Takimoto, R.; Tanaka, I.; Fujimi, A.; Akiyama, T.; Kuroda, H.; Kawano, Y.; Kobune, M. Interaction between leukemic-cell VLA-4 and stromal fibronectin is a decisive factor for minimal residual disease of acute myelogenous leukemia. Nat. Med. 2003, 9, 1158-1165. [CrossRef] [PubMed]

72. Corre, J.; Mahtouk, K.; Attal, M.; Gadelorge, M.; Huynh, A.; Fleury-Cappellesso, S.; Danho, C.; Laharrague, P.; Klein, B.; Rème, T. Bone marrow mesenchymal stem cells are abnormal in multiple myeloma. Leukemia 2007, 21, 1079-1088. [CrossRef] [PubMed]

73. Abdul-Aziz, A.M.; Shafat, M.S.; Mehta, T.K.; di Palma, F.; Lawes, M.J.; Rushworth, S.A.; Bowles, K.M. MIF-Induced Stromal PKC $\beta$ /IL8 Is Essential in Human Acute Myeloid Leukemia. Cancer Res. 2017, 77, 303-311. [CrossRef] [PubMed]

74. Alsayed, Y.; Ngo, H.; Runnels, J.; Leleu, X.; Singha, U.K.; Pitsillides, C.M.; Spencer, J.A.; Kimlinger, T.; Ghobrial, J.M.; Jia, X.; et al. Mechanisms of regulation of CXCR4/SDF-1 (CXCL12)-dependent migration and homing in multiple myeloma. Blood 2007, 109, 2708-2717. [CrossRef] [PubMed]

75. Rombouts, E.J.C.; Pavic, B.; Löwenberg, B.; Ploemacher, R.E. Relation between CXCR-4 expression, Flt3 mutations, and unfavorable prognosis of adult acute myeloid leukemia. Blood 2004, 104, 550-557. [CrossRef] [PubMed]

76. Lataillade, J.J.; Clay, D.; Dupuy, C.; Rigal, S.; Jasmin, C.; Bourin, P.; Le Bousse-Kerdiles, M.C. Chemokine SDF-1 enhances circulating CD34(+) cell proliferation in synergy with cytokines: Possible role in progenitor survival. Blood 2000, 95, 756-768. [PubMed]

77. Nefedova, Y.; Landowski, T.H.; Dalton, W.S. Bone marrow stromal-derived soluble factors and direct cell contact contribute to de novo drug resistance of myeloma cells by distinct mechanisms. Leukemia 2003, 17, 1175-1182. [CrossRef] [PubMed]

78. Nervi, B.; Ramirez, P.; Rettig, M.P.; Uy, G.L.; Holt, M.S.; Ritchey, J.K.; Prior, J.L.; Piwnica-Worms, D.; Bridger, G.; Ley, T.J.; et al. Chemosensitization of acute myeloid leukemia (AML) following mobilization by the CXCR4 antagonist AMD3100. Blood 2009, 113, 6206-6214. [CrossRef] [PubMed]

79. Ferrarini, M.; Steimberg, N.; Ponzoni, M.; Belloni, D.; Berenzi, A.; Girlanda, S.; Caligaris-Cappio, F.; Mazzoleni, G.; Ferrero, E. Ex Vivo dynamic 3-D culture of human tissues in the RCCS ${ }^{\mathrm{TM}}$ bioreactor allows the study of Multiple Myeloma biology and response to therapy. PLoS ONE 2013, 8, e71613. [CrossRef]

80. Antonelli, A.; Noort, W.A.; Jaques, J.; de Boer, B.; de Jong-Korlaar, R.; Brouwers-Vos, A.Z.; Lubbers-Aalders, L.; van Velzen, J.F.; Bloem, A.C.; Yuan, H.; et al. Establishing human leukemia xenograft mouse models by implanting human bone marrow-like scaffold-based niches. Blood 2016, 128, 2949-2959. [CrossRef] [PubMed]

81. Johnson, J.I.; Decker, S.; Zaharevitz, D.; Rubinstein, L.V.; Venditti, J.M.; Schepartz, S.; Kalyandrug, S.; Christian, M.; Arbuck, S.; Hollingshead, M.; et al. Relationships between drug activity in NCI preclinical in vitro and in vivo models and early clinical trials. Br. J. Cancer 2001, 84, 1424-1431. [CrossRef] [PubMed]

82. Artandi, S.E.; Chang, S.; Lee, S.L.; Alson, S.; Gottlieb, G.J.; Chin, L.; DePinho, R.A. Telomere dysfunction promotes non-reciprocal translocations and epithelial cancers in mice. Nature 2000, 406, 641-645. [PubMed]

83. Bendre, M.S.; Margulies, A.G.; Walser, B.; Akel, N.S.; Bhattacharrya, S.; Skinner, R.A.; Swain, F.; Ramani, V.; Mohammad, K.S.; Wessner, L.L.; et al. Tumor-derived interleukin-8 stimulates osteolysis independent of the receptor activator of nuclear factor-kappaB ligand pathway. Cancer Res. 2005, 65, 11001-11009. [CrossRef] [PubMed] 
84. Cacalano, G.; Lee, J.; Kikly, K.; Ryan, A.; Pitts-Meek, S.; Hultgren, B.; Wood, W.; Moore, M. Neutrophil and B cell expansion in mice that lack the murine IL-8 receptor homolog. Science 1994, 265, 682-684. [CrossRef] [PubMed]

85. Morton, J.J.; Bird, G.; Keysar, S.B.; Astling, D.P.; Lyons, T.R.; Anderson, R.T.; Glogowska, M.J.; Estes, P.; Eagles, J.R.; Le, P.N.; et al. XactMice: Humanizing mouse bone marrow enables microenvironment reconstitution in a patient-derived xenograft model of head and neck cancer. Oncogene 2016, 35, 290-300. [CrossRef] [PubMed]

86. Belnoue, E.; Pihlgren, M.; McGaha, T.L.; Tougne, C.; Rochat, A.-F.; Bossen, C.; Schneider, P.; Huard, B.; Lambert, P.-H.; Siegrist, C.-A. APRIL is critical for plasmablast survival in the bone marrow and poorly expressed by early-life bone marrow stromal cells. Blood 2008, 111, 2755-2764. [CrossRef] [PubMed]

87. Moreaux, J.; Legouffe, E.; Jourdan, E.; Quittet, P.; Rème, T.; Lugagne, C.; Moine, P.; Rossi, J.F.; Klein, B.; Tarte, K. BAFF and APRIL protect myeloma cells from apoptosis induced by interleukin 6 deprivation and dexamethasone. Blood 2004, 103, 3148-3157. [CrossRef] [PubMed]

88. Roosnek, E.; Burjanadze, M.; Dietrich, P.Y.; Matthes, T.; Passweg, J.; Huard, B. Tumors that look for their springtime in APRIL. Crit. Rev. Oncol./Hematol. 2009, 72, 91-97. [CrossRef] [PubMed]

89. Dudek, H.; Datta, S.R.; Franke, T.F.; Birnbaum, M.J.; Yao, R.; Cooper, G.M.; Segal, R.A.; Kaplan, D.R.; Greenberg, M.E. Regulation of Neuronal Survival by the Serine-Threonine Protein Kinase Akt. Science 1997, 275, 661-665. [CrossRef] [PubMed]

90. Sprynski, A.C.; Hose, D.; Caillot, L.; Reme, T.; Shaughnessy, J.D., Jr.; Barlogie, B.; Seckinger, A.; Moreaux, J.; Hundemer, M.; Jourdan, M.; et al. The role of IGF-1 as a major growth factor for myeloma cell lines and the prognostic relevance of the expression of its receptor. Blood 2009, 113, 4614-4626. [CrossRef] [PubMed]

91. Glassford, J.; Rabin, N.; Lam, E.W.; Yong, K.L. Functional regulation of D-type cyclins by insulin-like growth factor-I and serum in multiple myeloma cells. Br. J. Haematol. 2007, 139, 243-254. [CrossRef] [PubMed]

92. Chapuis, N.; Tamburini, J.; Cornillet-Lefebvre, P.; Gillot, L.; Bardet, V.; Willems, L.; Park, S.; Green, A.S.; Ifrah, N.; Dreyfus, F.; et al. Autocrine IGF-1/IGF-1R signaling is responsible for constitutive PI3K/Akt activation in acute myeloid leukemia: Therapeutic value of neutralizing anti-IGF-1R antibody. Haematologica 2010, 95, 415-423. [CrossRef] [PubMed]

93. Piddock, R.E.; Abdul-Aziz, A.M.; Auger, M.J.; Bowles, K.M.; Rushworth, S.A. Macrophage Migration Inhibitory Factor Drives Multiple Myeloma IL-6/8 Pro-Survival Signals in the Tumor Microenvironment. Blood 2015, 126, 2988-2988.

94. Fan, F.; Vallet, S.; Sattler, M.; Tonon, G.; Bashari, M.H.; Bakiri, L.; Goldschmidt, H.; Wagner, E.F.; Jaeger, D.; Podar, K. The AP-1 Transcription Factor JunB Promotes Multiple Myeloma (MM) Cell Proliferation, Survival and Drug Resistance in the Bone Marrow Microenvironment. Blood 2014, 124, 3446-3446. [CrossRef]

95. Hideshima, T.; Nakamura, N.; Chauhan, D.; Anderson, K.C. Biologic sequelae of interleukin-6 induced PI3-K/Akt signaling in multiple myeloma. Oncogene 2001, 20, 5991-6000. [CrossRef] [PubMed]

96. Wegiel, B.; Bjartell, A.; Culig, Z.; Persson, J.L. Interleukin-6 activates PI3K/Akt pathway and regulates cyclin A1 to promote prostate cancer cell survival. Int. J. Cancer 2008, 122, 1521-1529. [CrossRef] [PubMed]

97. Herrero, A.B.; Garcia-Gomez, A.; Garayoa, M.; Corchete, L.A.; Hernandez, J.M.; San Miguel, J.; Gutierrez, N.C. Effects of IL-8 Up-Regulation on Cell Survival and Osteoclastogenesis in Multiple Myeloma. Am. J. Pathol. 2016, 186, 2171-2182. [CrossRef] [PubMed]

98. Schinke, C.; Giricz, O.; Li, W.; Shastri, A.; Gordon, S.; Barreyro, L.; Bhagat, T.; Bhattacharyya, S.; Ramachandra, N.; Bartenstein, M.; et al. IL8-CXCR2 pathway inhibition as a therapeutic strategy against MDS and AML stem cells. Blood 2015, 125, 3144-3152. [CrossRef] [PubMed]

99. Shao, N.; Lu, Z.; Zhang, Y.; Wang, M.; Li, W.; Hu, Z.; Wang, S.; Lin, Y. Interleukin-8 upregulates integrin $\beta 3$ expression and promotes estrogen receptor-negative breast cancer cell invasion by activating the PI3K/Akt/NF-kB pathway. Cancer Lett. 2015, 364, 165-172. [CrossRef] [PubMed]

100. Terpos, E.; Politou, M.; Viniou, N.; Rahemtulla, A. Significance of macrophage inflammatory protein-1 alpha (MIP-1alpha) in multiple myeloma. Leuk. Lymphoma 2005, 46, 1699-1707. [CrossRef] [PubMed]

101. Tsubaki, M.; CKato; Manno, M.; Ogaki, M.; Satou, T.; Itoh, T.; Kusunoki, T.; Tanimori, Y.; Fujiwara, K.; Matsuoka, H.; et al. Macrophage inflammatory protein-1 $\alpha$ (MIP-1 $\alpha)$ enhances a receptor activator of nuclear factor $\mathrm{\kappa B}$ ligand (RANKL) expression in mouse bone marrow stromal cells and osteoblasts through MAPK and PI3K/Akt pathways. Mol. Cell. Biochem. 2007, 304, 53-60. [CrossRef] [PubMed] 
102. Zaitseva, L.; Murray, M.Y.; Shafat, M.S.; Lawes, M.J.; MacEwan, D.J.; Bowles, K.M.; Rushworth, S.A. Ibrutinib inhibits SDF1/CXCR4 mediated migration in AML. Oncotarget 2014, 5, 9930-9938. [CrossRef] [PubMed]

103. Voermans, C.; Van Heese, W.; De Jong, I.; Gerritsen, W.; van Der Schoot, C. Migratory behavior of leukemic cells from acute myeloid leukemia patients. Leukemia 2002, 16, 650-657. [CrossRef] [PubMed]

104. Barbero, S.; Bonavia, R.; Bajetto, A.; Porcile, C.; Pirani, P.; Ravetti, J.L.; Zona, G.L.; Spaziante, R.; Florio, T.; Schettini, G. Stromal Cell-derived Factor $1 \alpha$ Stimulates Human Glioblastoma Cell Growth through the Activation of Both Extracellular Signal-regulated Kinases 1/2 and Akt. Cancer Res. 2003, 63, 1969-1974. [PubMed]

105. Mitsiades, N.; Mitsiades, C.S.; Poulaki, V.; Chauhan, D.; Richardson, P.G.; Hideshima, T.; Munshi, N.; Treon, S.P.; Anderson, K.C. Biologic sequelae of nuclear factor-kappaB blockade in multiple myeloma: Therapeutic applications. Blood 2002, 99, 4079-4086. [CrossRef] [PubMed]

106. Oster, W.; Cicco, N.A.; Klein, H.; Hirano, T.; Kishimoto, T.; Lindemann, A.; Mertelsmann, R.H.; Herrmann, F. Participation of the cytokines interleukin 6, tumor necrosis factor-alpha, and interleukin 1-beta secreted by acute myelogenous leukemia blasts in autocrine and paracrine leukemia growth control. J. Clin. Investig. 1989, 84, 451-457. [CrossRef] [PubMed]

107. Smith, M.V.; Lee, M.J.; Islam, A.S.; Rohrer, J.L.; Goldberg, V.M.; Beidelschies, M.A.; Greenfield, E.M. Inhibition of the PI3K-Akt signaling pathway reduces tumor necrosis factor-alpha production in response to titanium particles in vitro. J. Bone Jt. Surg. Am. 2007, 89, 1019-1027.

108. Gupta, D.; Treon, S.; Shima, Y.; Hideshima, T.; Podar, K.; Tai, Y.; Lin, B.; Lentzsch, S.; Davies, F.; Chauhan, D. Adherence of multiple myeloma cells to bone marrow stromal cells upregulates vascular endothelial growth factor secretion: Therapeutic applications. Leukemia 2001, 15, 1950-1961. [CrossRef] [PubMed]

109. Aguayo, A.; Kantarjian, H.; Manshouri, T.; Gidel, C.; Estey, E.; Thomas, D.; Koller, C.; Estrov, Z.; O’Brien, S.; Keating, M.; et al. Angiogenesis in acute and chronic leukemias and myelodysplastic syndromes. Blood 2000, 96, 2240-2245. [PubMed]

110. Fiedler, W.; Graeven, U.; Ergün, S.; Verago, S.; Kilic, N.; Stockschläder, M.; Hossfeld, D.K. Vascular Endothelial Growth Factor, a Possible Paracrine Growth Factor in Human Acute Myeloid Leukemia. Blood 1997, 89, 1870-1875. [PubMed]

111. Takahashi, M.; Matsui, A.; Inao, M.; Mochida, S.; Fujiwara, K. ERK/MAPK-dependent PI3K/Akt phosphorylation through VEGFR-1 after VEGF stimulation in activated hepatic stellate cells. Hepatol. Res. 2003, 26, 232-236. [CrossRef]

112. Miller, T.W.; Rexer, B.N.; Garrett, J.T.; Arteaga, C.L. Mutations in the phosphatidylinositol 3-kinase pathway: Role in tumor progression and therapeutic implications in breast cancer. Breast Cancer Res. 2011, 13. [CrossRef] [PubMed]

113. Hess, G.; Herbrecht, R.; Romaguera, J.; Verhoef, G.; Crump, M.; Gisselbrecht, C.; Laurell, A.; Offner, F.; Strahs, A.; Berkenblit, A.; et al. Phase III study to evaluate temsirolimus compared with investigator's choice therapy for the treatment of relapsed or refractory mantle cell lymphoma. J. Clin. Oncol. 2009, 27, 3822-3829. [CrossRef] [PubMed]

114. Choo, A.Y.; Yoon, S.O.; Kim, S.G.; Roux, P.P.; Blenis, J. Rapamycin differentially inhibits S6Ks and 4E-BP1 to mediate cell-type-specific repression of mRNA translation. Proc. Natl. Acad. Sci. USA 2008, 105, 17414-17419. [CrossRef] [PubMed]

115. Mothe-Satney, I.; Yang, D.; Fadden, P.; Haystead, T.A.J.; Lawrence, J.C. Multiple Mechanisms Control Phosphorylation of PHAS-I in Five (S/T)P Sites That Govern Translational Repression. Mol. Cell. Biol. 2000, 20, 3558-3567. [CrossRef] [PubMed]

116. Zhou, J.; Schmid, T.; Frank, R.; Brüne, B. PI3K/Akt is required for heat shock proteins to protect hypoxia-inducible factor $1 \alpha$ from pVHL-independent degradation. J. Biol. Chem. 2004, 279, 13506-13513. [CrossRef] [PubMed]

117. Sims, J.D.; McCready, J.; Jay, D.G. Extracellular heat shock protein (Hsp) 70 and Hsp90 $\alpha$ assist in matrix metalloproteinase-2 activation and breast cancer cell migration and invasion. PLoS ONE 2011, 6, e18848. [CrossRef] [PubMed]

118. Cornford, P.A.; Dodson, A.R.; Parsons, K.F.; Desmond, A.D.; Woolfenden, A.; Fordham, M.; Neoptolemos, J.P.; Ke, Y.; Foster, C.S. Heat shock protein expression independently predicts clinical outcome in prostate cancer. Cancer Res. 2000, 60, 7099-7105. [PubMed] 
119. Kimura, E.; Enns, R.E.; Alcaraz, J.E.; Arboleda, J.; Slamon, D.J.; Howell, S.B. Correlation of the survival of ovarian cancer patients with mRNA expression of the 60-kD heat-shock protein HSP-60. J. Clin. Oncol. 1993, 11, 891-898. [CrossRef] [PubMed]

120. Chatterjee, M.; Jain, S.; Stuhmer, T.; Andrulis, M.; Ungethum, U.; Kuban, R.J.; Lorentz, H.; Bommert, K.; Topp, M.; Kramer, D.; et al. STAT3 and MAPK signaling maintain overexpression of heat shock proteins 90alpha and beta in multiple myeloma cells, which critically contribute to tumor-cell survival. Blood 2007, 109, 720-728. [CrossRef] [PubMed]

121. Reikvam, H.; Nepstad, I.; Sulen, A.; Gjertsen, B.T.; Hatfield, K.J.; Bruserud, O. Increased antileukemic effects in human acute myeloid leukemia by combining HSP70 and HSP90 inhibitors. Expert Opin. Investig. Drugs 2013, 22, 551-563. [CrossRef] [PubMed]

122. Ying, W.; Du, Z.; Sun, L.; Foley, K.P.; Proia, D.A.; Blackman, R.K.; Zhou, D.; Inoue, T.; Tatsuta, N.; Sang, J.; et al. Ganetespib, a Unique Triazolone-Containing Hsp90 Inhibitor, Exhibits Potent Antitumor Activity and a Superior Safety Profile for Cancer Therapy. Mol. Cancer Ther. 2012, 11, 475-484. [CrossRef] [PubMed]

123. Yao, Q.; Nishiuchi, R.; Kitamura, T.; Kersey, J.H. Human leukemias with mutated FLT3 kinase are synergistically sensitive to FLT3 and Hsp90 inhibitors: The key role of the STAT5 signal transduction pathway. Leukemia 2005, 19, 1605-1612. [CrossRef] [PubMed]

124. Chia, S.; Gandhi, S.; Joy, A.A.; Edwards, S.; Gorr, M.; Hopkins, S.; Kondejewski, J.; Ayoub, J.P.; Califaretti, N.; Rayson, D.; et al. Novel agents and associated toxicities of inhibitors of the pi3k/Akt/mtor pathway for the treatment of breast cancer. Curr. Oncol. 2015, 22, 33-48. [CrossRef] [PubMed]

125. Yang, Q.; Modi, P.; Newcomb, T.; Queva, C.; Gandhi, V. Idelalisib: First-in-Class PI3K Delta Inhibitor for the Treatment of Chronic Lymphocytic Leukemia, Small Lymphocytic Leukemia, and Follicular Lymphoma. Clin. Cancer Res. 2015, 21, 1537-1542. [CrossRef] [PubMed]

126. Jain, N.; O'Brien, S. Initial treatment of CLL: Integrating biology and functional status. Blood 2015, 126, 463-470. [CrossRef] [PubMed]

127. Agata, Y.; Kawasaki, A.; Nishimura, H.; Ishida, Y.; Tsubat, T.; Yagita, H.; Honjo, T. Expression of the PD-1 antigen on the surface of stimulated mouse T and B lymphocytes. Int. Immunol. 1996, 8, 765-772. [CrossRef] [PubMed]

128. Topalian, S.L.; Drake, C.G.; Pardoll, D.M. Targeting the PD-1/B7-H1(PD-L1) pathway to activate anti-tumor immunity. Curr. Opin. Immunol. 2012, 24, 207-212. [CrossRef] [PubMed]

129. Patsoukis, N.; Li, L.; Sari, D.; Petkova, V.; Boussiotis, V.A. PD-1 Increases PTEN Phosphatase Activity While Decreasing PTEN Protein Stability by Inhibiting Casein Kinase 2. Mol. Cell. Biol. 2013, 33, 3091-3098. [CrossRef] [PubMed]

130. Shepherd, C.; Banerjee, L.; Cheung, C.; Mansour, M.; Jenkinson, S.; Gale, R.; Khwaja, A. PI3K/mTOR inhibition upregulates NOTCH-MYC signalling leading to an impaired cytotoxic response. Leukemia 2013, 27, 650-660. [CrossRef] [PubMed]

131. Serra, V.; Scaltriti, M.; Prudkin, L.; Eichhorn, P.J.A.; Ibrahim, Y.H.; Chandarlapaty, S.; Markman, B.; Rodriguez, O.; Guzman, M.; Rodriguez, S.; et al. PI3K inhibition results in enhanced HER signaling and acquired ERK dependency in HER2-overexpressing breast cancer. Oncogene 2011, 30, 2547-2557. [CrossRef] [PubMed]

132. Balakrishnan, K.; Peluso, M.; Fu, M.; Rosin, N.Y.; Burger, J.A.; Wierda, W.G.; Keating, M.J.; Faia, K.; O’Brien, S.; Kutok, J.L.; et al. The phosphoinositide-3-kinase (PI3K)-delta and gamma inhibitor, IPI-145 (Duvelisib), overcomes signals from the PI3K/AKT/S6 pathway and promotes apoptosis in CLL. Leukemia 2015, 29, 1811-1822. [CrossRef] [PubMed]

(C) 2017 by the authors. Licensee MDPI, Basel, Switzerland. This article is an open access article distributed under the terms and conditions of the Creative Commons Attribution (CC BY) license (http:/ / creativecommons.org/licenses/by/4.0/). 